\title{
Los pobres sujetos de pobreza: Iglesia, sociedad, caridad cristiana y beneficiencia estatal en el siglo XIX.
}

\author{
José Domínguez SAN MaRTín
}

\begin{abstract}
RESUMEN
En la primera mitad del siglo XIX hay una evolución a la respuesta del problema que plantea la pobreza y la ingente masa de pobres, que ya se viene produciendo, sobre todo, desde el siglo XVI. Es el paso de

una caridad Cristiana a una beneficiencia estatal acentuado $y$ agudizado por la secularización de

la sociedad, la desamortización, las guerras, etc... A ello hay que darle respuestas, que antes eran dadas, prioritariamente, por y desde la Iglesia y que ahora

las acaparará el Estado.

PALABRAS CLAVE

Caridad cristiana, pobreza, pobres, Estado, Iglesia, siglo XIX, beneficiencia, desamportización, secularización teología de la caridad.
\end{abstract}

\begin{abstract}
SUMMARY
In the first half of $19^{\text {th }}$ centurythe response $t /$ the problem of poverty and the immense amount of impoverished people evolved.

The increa in povery has beeen progressively growing, especially since the $16^{\text {th }}$ century. It is the transition from christiam charity to state assistance, supported by the secularization of society, the sale of church lands, wars, etc...

To this answers had to be given by the state that were previorisly given by the church
\end{abstract}

\section{KEYWORDS}

Christian charity, poverty, impoverished people, State Church, 19 th century, sale of church lands, secularization, state assistence, teology of charity

\section{INTRODUCCIÓN}

El objeto de este artículo es dar a conocer, y profundizar en una de las cuestiones del siglo XIX muy preocupantes, como es los sujetos de la pobreza: los pobres. Cuál es el contexto histórico, social, económico, político, religioso, etc... que les envuelve y en el que se desenvuelven los acontecimientos y hechos que llegan a hacer posible esta cruda realidad. Cuál es la visión eclesiológica y teológica de la pobreza, y qué respuestas se dan a la misma. Qué concepción tiene el Estado, la Iglesia y la sociedad, en general, de este momento histórico sobre de la pobreza. Pues de 
todo ello dependerá la posición y las actitudes que se tomarán al respecto en la causa de los pobres.

En definitiva, la pretensión es llegar a conocer cómo en esta primera mitad del siglo XIX se da el paso de una caridad cristiana (religiosa, eclesial), pues hasta el momento la Iglesia es la protagonista por excelencia de la atención para con los pobres, a una beneficencia laica (secularizada, estatal), que a partir de finales del siglo XVIII y a lo largo del siglo XIX tomará las riendas y relegará a la Iglesia a un segundo plano, absorbiéndole ese protagonismo histórico que le caracterizaba.

\section{SITUACIÓN DE LA IGLESIA EN EL SIGLO XIX}

La Iglesia española se encuentra al comenzar el siglo XIX en una situación de triste sujeción al Estado. El regalismo era imperante e insoportable. Los reyes (Carlos IV, José I, Fernando VII) y sus ministros (Godoy, Urquijo, Caballero, etc...) ponían y quitaban mitras y cargos eclesiásticos a su antojo; daban disposiciones y metían mano a los bienes eclesiásticos a su capricho, y las presiones sobre Roma estaban al día ${ }^{1}$.

La Iglesia española, la sociedad y, en general el pueblo español de comienzos del siglo XIX se encuentra con uno de los acontecimientos más importantes que marca el ritmo del siglo XIX: la guerra de la Independencia.

El tema dominante de este siglo es la lucha en torno a la secularización de la vida española. Aunque se trata de un proceso análogo al de otros países de cultura católica mayoritaria, en España se destacan algunas notas características: su larga duración, su violencia (guerras civiles frecuentes) y la falta de una corriente apreciable de pensamiento católico-liberal ${ }^{2}$.

A partir de 1808 hasta el último cuarto del siglo XIX el catolicismo español atraviesa uno de los períodos más agitados de su historia. Pues, en primer lugar, comienza con la gran revolución liberal que tuvo su origen en las Cortes de Cádiz y llegando a su cima en la revolución de 1868 en medio de avances y retrocesos.

La Iglesia Católica, que a lo largo de los siglos había sido el alma y el espíritu de la nación, se vio acosada por poderosos influjos ambientales e ideologías y sufrió hondas transformaciones.

La Iglesia del Antiguo Régimen era un cuerpo imponente por su poder y riqueza. Estaba dotada de una clerecía abundante, más prestigiada por su rango y su prevalencia social que por ia autenticidad de su testimonio espiri-

Cfr. JimÉnEZ DuQUe, B., La espiritualidad en el siglo XIX español, Ed. UPSA, Madrid, 1974, pág. 27.

${ }^{2}$ Cfr. Gutiértrez NIETo, R., «Historia de la Iglesia Española, siglos XIX-XX», en Gran Enciclopedia Rialp, T. IX, Ed. Rialp, Madrid, 1972, pág. 81. 
tual. La Iglesia lo llenaba todo: era el sostén del Estado al que legitimaba con su alianza y ayudaba con sus diezmos. No se concebía enseñanza ni beneficencia que no estuvieran de algún modo amparadas por las instituciones eclesiásticas, ni era posible pensar nada que se apartase de la doctrina católica sin caer en la vigilancia del Santo Oficio ${ }^{3}$.

Aquella España íntegramente católica, en la que la religión, Estado y sociedad aparecían fundidos sin fisuras, se fue transformando en el decurso de las siguientes décadas, pues a partir de los setenta la unidad católica queda sustituida por la libertad religiosa.

Las ciudades que estaban superpobladas de edificios religiosos van dando lugar a teatros, plazas y avenidas, donde antes había conventos. El clero ha perdido sus privilegios y la Iglesia sus riquezas. La Iglesia y el Estado corren caminos paralelos, o a veces, divergentes. Nuevos cultos, nuevas doctrinas hacen acto de presencia de forma insólita y desconocida. Es, pues, la consumación de la ruptura entre la Iglesia, el Estado y la sociedad. Se ha dado el paso de una sociedad de cristiandad a una sociedad en libertad ${ }^{4}$.

Por tanto, se pasa del tránsito, de un catolicismo exclusivo e inquisitorial (lento y penoso) a un sistema de libertad religiosa impulsado sobre todo por la revolución liberal.

Tres por tanto serán los estadios por los que ha de atravesar: el primero serán las nuevas ideas que traerá la llustración que se irán imponiendo paulatinamente (a medida que se liquida el Antiguo Régimen, sufre un lento derrumbe de su estructura antigua; en segundo lugar la lucha contra el invasor francés; y en un tercer momento, la revolución liberal, que se impondrá definitivamente a partir de principios del segundo tercio del siglo (vive unos años de compromiso concordatario en los que pretende recuperar la pérdida que le supone el liberalismo, bajo el partido moderado, para, después, durante el sexenio entrar en una nueva relajación durante el gobierno de los demócratas triunfantes en 1868.

La fuerza del sentimiento religioso, que no fue el único motivo, que impulsó a los españoles al levantamiento, estriba en su carácter eminentemente popular, era el pueblo que luchaba por amor a la religión, a su rey y a su patria ${ }^{5}$.

A partir de 1808, será Napoleón el que estará al frente de la situación de España imponiendo su voluntad a través de su hermano José I, que será nombrado rey de España.

3. Cfr. Revuelta González, M., "Religión y formas de religiosidad", en Historia de España, Menéndez Pidal, T. XXXV, La Época del Romanticismo (1808-1874), Vol. I, Ed. Espasa-Calpe, 1989, pág. 215.

${ }^{4}$ Cfr. lbid., pág. 216.

${ }^{5}$ Cfr. Revuelta GonzÁlez, J.M., “La lglesia en la España Contemporánea (1808-1975)», en Historia de la Iglesia en España, T. V. Ed. BAC Maior 20, Madrid, 1979, pág. 7. 
Entre las medidas más importantes destacan las tomadas contra algunas clases privilegiadas e instituciones gubernativas del Antiguo Régimen. Suprimió el santo Oficio, y sus bienes incorporados a la Corona. Los conventos quedaron reducidos. No impone la tolerancia de cultos. Pero más adelante una de las medidas tomadas por José I será la supresión de los conventos de regulares y de las Órdenes Militares, como a así mismo, todo lo relativo a la desamortización eclesiástica.

\section{PERÍODO DE LAS CORTES DE CÁDIZ (CONSTITUYENTE)}

Es característico de esta etapa de la historia el ritmo del proceso, con momentos unos más cortos y otros más largos de secularización, seguidos de largos períodos de restauración.

En el período de las Cortes Constituyentes (18010-13), se dictan decretos suprimiendo la Inquisición, se desamortizan parcialmente los bienes eclesiásticos y se establece la libertad de imprenta. Aunque, la vuelta de Fernando VII en 1814 frena este proceso secularizador, salvo el corto y violento momento del paréntesis revolucionario que va de 1820 a $1823^{6}$.

Las Cortes de Cádiz hicieron una revolución política en nombre de la tradición. En ella se dan aspectos democráticos y conservadores. Se da una síntesis de tendencias opuestas. Sobre la base de una religión tradicional venerada en toda su pureza y con el pretexto de protegerla, los innovadores han logrado implantar la táctica regalista de prevalencia estatal sobre la Iglesia ${ }^{7}$.

Sobre las disposiciones tomadas destacamos las más importantes: el reconocimiento incuestionable de la religión católica, apostólica y romana ${ }^{8}$; exigencia del apoyo moral y material de la Iglesia ${ }^{9}$; la supresión del Santo Oficio ${ }^{10}$; planes para la realización de un concilio nacional que no se llevó a cabo; Restablecimiento y reforma de los conventos; comienzo de una tímida desamortización eclesiástica.

${ }^{6}$ Cfr. Gutiérrez Nieto, R., «Historia de la Iglesia, siglos XIX y XX» en Gran Enciclopedia Riapl, Ed. Rialp, Madrid, 1972.

${ }^{7}$ Cfr. Revuelta Manuel, M., o.c. pág. 41.

- La nación española profesa la religión católica, apostólica, romana, única verdadera, con exclusión de cualquiera otra. (Art. 12 del Diario de Cortes ses. del 2 y $3-I X-1811$ t. 8 pág. 119-120).

${ }^{9}$ Las Cortes imponen las funciones litúrgicas y directrices pastorales... de dispones el poder civil de acciones de gracias, rogativas y pompas fúnebres... imponer al clero la reforma de costumbres y el rechazo al enemigo... . Varios obispos y monasterios pusieron sus bienes al servicio de la causa nacional los bienes eclesiásticos... . Reclamarian de los cabildos y párrocos la entrega de caudales o diezmos... entrega de alajas y plata de las iglesias que no fueran necesarias para el culto... los productos de toda obra pía que no estuviera aplicada al mantenimiento de hospitales, hospicios y casas de misericordia o educación. Cfr. Revuelta González, M., o.c. pág. 44.

${ }^{10}$ Por un lado, hubo defensores del mantenimiento de la Inquisición y, por otro, detractores a favor de la desaparición de dicho tribunal. Arguían razones de todo tipo, unas de orden político, y, otras, de orden religioso. Por ejemplo, decian en contra que "la Inquisición se oponía a la letra de la Constitución... se oponía al espíritu del nuevo código, a la libertad, a la independencia de la nación... a la libertad individual... al sentir de los pueblo... (Cfr. Argüelles, ses. Del 9-1-1813, pág. 127-143). 


\section{EL SEXENIO ABSOLUTISTA}

El 22 de marzo de 1814 vuelve Fernando VII, «el Deseado», que encuentra una España distinta a la que dejó seis años antes. Recibía un país desolado por los desastres de la guerra y las tensiones ideológicas y sociales.

La Iglesia había padecido profundas heridas en sus bienes, instituciones y cuerpos clericales. Los conventos habían quedado destruidos, saqueados o destrozados en gran parte en España. Los seminarios vaciados y los claustros despoblados, a causa de la guerra. Los clérigos vagaban por los pueblos empleados en distintos trabajos $u$ oficios distintos a su estado. Otros se habían secularizado.

En tales circunstancias la Iglesia pidió ayuda al rey quien le tendió la mano generosamente y así cumplía una deuda de gratuidad con la Iglesia satisfaciendo su piedad personal y así lograba el apoyo político de enorme entidad para su trono absoluto.

Los presupuestos ideológicos de la restauración se basaban en la alianza entre el trono y el altar. Un trono absoluto, basado en el legitismo dinástico de origen divino, y de un altar concebido con todos los aderezos, privilegios e inmunidades de la Iglesia antigua ${ }^{11}$.

El rey es exaltado con grandes adulaciones, como portador de las grandes virtudes, mientras los afrancesados y liberales reciben los mayores denuestos. El sistema liberal queda anatematizado, como algo perverso; es una falsa filosofía nacida del enciclopedismo, del jansenismo y del ateísmo. Al igual que la doctrina sobre la soberanía popular que es considerada una herejía, pues siendo Dios el autor de la soberanía temporal y de la espiritual, tanto le ofende el que le ataca de una u otra manera ${ }^{12}$.

\section{COOPERACIÓN DE LA IGLESIA AL RESTABLECIMIENTO DE LOS ÁNIMOS, LA MORALIDAD Y LA BENEFICENCIA}

La unión del Trono y el Altar presupone la confluencia de unos servicios y ayudas mutuas. El rey pidió la colaboración de la Iglesia la cual no sólo se redujo a los campos de la pastoral, como vigilancia de la ortodoxia, la corrección de costumbres o los servicios caritativos de la educación y la beneficencia, sino que se extendió a la prestación de los auxilios económicos que apuntalaban la quebrantada hacienda pública.

Además, de la ayuda que el Trono pidió a la Iglesia en la corrección de la relajación de costumbres, vida licenciosa, etc... para refrenar los vicios de la

"Cfr. Revuelta González, M., "La Iglesia española y el Antiguo Régimen» en Historia de la Iglesia, Ed. BAC, T. V. Madrid, 1979, pág. 68.

12 lbid., pág. 68-68 
irreligiosidad y el libertinaje, producidos por la guerra y las ideas liberarles, pidió la colaboración de la Iglesia en funciones caritativas de carácter social, como los centros de educación y enseñanza sostenidos con el personal y los bienes eclesiásticos; el sostenimiento de varios establecimientos de beneficencia, pues, el país sufría y padecía de calamidades por doquier debido a la destrucción y miseria de las casas de misericordia. Restableció el fondo pío beneficial. Los establecimientos caritativos fueron objeto de espacial desvelos: los hospitales, las casas de expósitos, los hospicios, las inclusas, etc... También, se organizó la hospitalidad domiciliaria (asistencia médica gratuita), en los barrios más pobres con los fondos del indulto cuadragesimal $^{13}$. (En Madrid no se noto esta especial dedicación de la Iglesia. La asistencia domiciliaria estaba ya establecida por el Plan de Beneficencia creado por Carlos III, Fernando VII solamente amplio a un mayor número de barrios este tipo de asistencia que llevaban a cabo las diputaciones de Barrio, dirigidas por un alcalde de Barrio y unos diputados, asociaciones de corte ilustrado que contaban ya muy poco con la ayuda de las parroquias)

Ciertamente, hay que reseñar que en estos momentos aunque las estructuras podían ser viciosas y anticuadas, la Iglesia siempre contribuyó con gusto y agrado a estas llamadas como cosa propia no faltando las iniciativas generosas que destacaron por su espíritu de caridad. Pues, gran parte de las rentas eclesiásticas, mermadas en estos momentos revertían en el alivio de las clases más necesitadas y en la atención a servicios de utilidad social.

\section{LA IGLESIA DESDE EL TRIENIO CONSTITUCIONAL (1820-23), LA ETAPA LIBERAL (1833) HASTA MEDIADOS DE SIGLO.}

En el período de Cortes Constituyentes (1810-13) se dictan decretos suprimiendo la Inquisición, se desamortizan parcialmente los bienes eclesiásticos y se establece una libertad de imprenta. Aunque con la vuelta de Fernando VII el 1814 se frena este proceso seculalizador hasta su muerte en 1833. Uno de los hechos que podemos destacar dentro del reinado de Fernando VII en la reposición de la Compañía de Jesús, suprimida en el reinado de Carlos III.

\section{PRINCIPALES MANIFESTACIONES JURIDICO-INSTITUCIONALES ACERCA DE LA BENEFICENCIA}

Es durante el reinado de Carlos III cuando se produce la transición hacia un sistema público de beneficencia, aunque no reciba todavía este nombre. Se introduce la expresión beneficencia, con todo su carácter secularizador en la Constitución de la Monarquía Española promulgada en Cádiz el 19 de

${ }^{13}$.Cfr. Revuelta González, M., o.c. pág. 78-79 
marzo de 1812. En ella decretaron las Cortes de Cádiz que las casas de misericordia y demás establecimientos benéficos costeados por el común corrieran en adelante a cargo de los ayuntamientos, el cuidar de los hospitales, hospicios, casas de expósitos y demás establecimientos de beneficencia (art. $321,6^{\circ}$ de la Constitución), y de las Diputaciones Provinciales «cuidar de que los establecimientos piadosos y de beneficencia llenen su respectivo objeto, proponiendo al Gobierno las reglas que estimen conducentes para la reforma de los abusos que se observaren" (art. 335, $8^{\circ}$ ).

Las disposiciones que las Cortes de Cádiz dictaron sobre la beneficencia fueron anuladas a la vuelta de Fernando VII; pero en 1820 se restableció la Constitución de 1812, lo que supuso que se desarrollaran los preceptos expuestos en la Constitución de 1812 a lo largo del Trienio Liberal (1820-1823).

La ley que se dio el 6 de febrero de1822 es un paso decisivo que considera a la beneficencia como un servicio público, destacando los siguientes puntos, como: la creación de las Juntas generales de beneficencia; la administración de los fondos de beneficencia; cuáles son los establecimientos de administración de beneficencia (casas de socorro). Así, pues, la estructura asistencial estaba basada en justas municipales; juntas parroquiales; juntas provinciales y juntas generales. Y las prestaciones asistenciales se reducian a la hospitalidad domiciliaria, la hospitalidad pública, casas de socorro, socorros domiciliarios, hospicios y casas de maternidad ${ }^{14}$.

El período de regencias (1833-44), se desarrolla en medio de una guerra civil generalizada.

Con la muerte de Fernando VII (29 de septiembre de 1833) se inicia una nueva etapa en la historia contemporánea de España, dejando como herencia a su hija Isabel una sangrienta guerra civil en el territorio español y las bases para poder establecer el nuevo régimen liberal.

Durante la minoría de edad de Isabel, fue su madre la que actuó como regente, que aunque no era muy proclive al liberalismo, por defender los derechos de su hija Isabel al trono convino con los liberales, los más templados, para llevar a cabo sus pretensiones, tanto María Cristina como los liberales.

Por otra parte, el infante $\mathrm{D}$. Carlos se negó a reconocer la legitimidad de la princesa de Asturias para ocupar el trono de España, pues, se creía con más derechos al trono.

${ }^{14} \mathrm{Cfr}$. Martínez Alcubilla, M., «Diccionario de la administración española» Impr. De v. E hijas de D.P. Peñuelas, Calatraba, 8. Ed. 3, Tomo I, Madrid, 1887, págs. 878-885. Cfr. Alonso Seco, J.M., y Gonzalo González, B., La asistencia social y los servicios sociales en España, en Estudios Jurídicos, Serie Derecho Público, B.O.E.,1997, págs. 57-58. Cfr. Susín Betrán, R., La regulación de la pobreza. El tratamiento jurídico-político de la pobreza: Los ingresos mínimos de insercción. En Colección jurídica, nº. 13, Ed. Universidad de La Rioja. Servicio de publicaciones, pág, 103 y ss. 
Razones que se pueden aducir de la causa carlista, entre otras, se explica la defensa del elemento foral, la resistencia a la descomposición de las formas de vida tradicionales frente a la oposición revolucionaria del liberalismo: igualdad, libertad y fraternidad; una lucha del campo contra la ciudad, etc...

\section{ÉPOCA ISABELINA Y ETAPA MODERADA}

Entramos ahora en una nueva etapa de restauración con el reinado de Isabel II (1844-1868).

Durante los años, 40 y 50 siguieron una serie de leyes, decretos y reglamentos que estatalizaron más si cabe la beneficencia. Sobre todo, la ley de Beneficencia de 20 de junio de 1849 y el Reglamento de ejecución de 14 de mayo de 1852, prosiguen el proceso secularizador anteriormente iniciado, y sobre el que incidirá, las medidas desamortizadoras (1 de mayo de 1855), y va a significar la consolidación de la beneficencia como servicio público.

Isabel II es una mujer de un marcado carácter, espontánea, llena de vitalidad. Pero, como afirma Sánchez Montero, «nunca supo entender el papel de arbitraje que le correspondía a la corona... y a la hora de tomar decisiones "nunca actuó por iniciativa propia... con frecuencia se hablaba de la camarilla que rodeaba a la reina» 15 .

El tránsito al modernismo culminó cuando el dos de mayo de 1844 la reina nombraba un gobierno presidido por Narváez. Fue un momento en que los moderados aprovecharon para llevar sus ideas a la práctica. Por un lado, están la fracción viluma, que preconiza la reconciliación nacional, una síntesis entre tradición y revolución. En el otro extremo, estaban los puritanos, sector que buscaba un moderantismo estrictamente legal y constitucional. Y por último, está la gran masa de centrista de los moderados, liderados por Narváez, quien con su autoridad va a llenar la primera etapa isabelina.

La Constitución de 1845 es un documento que expresa con exactitud el ideario político del moderantismo. Se omite la mención a la soberanía nacional y se incluye el principio de la soberanía compartida, más en consonancia con el ideario moderado.

Después de ser promulgada la nueva Constitución de 1845, la situación de los establecimientos era deficitaria. Va a ser, sobre todo entre 1847 y 1855 cuando se pongan las bases legales del nuevo sistema de beneficencia liberal, que ya cuenta con los antecedentes legales mencionados, se

${ }^{15}$ Cfr. Martínez Velasco de, A., Montero, F., Sánchez Montero, R., Manual de Historia de España. Siglo XIX, Ed. Historia 16,pág. 202-203 
pretende una organización de la asistencia, pero la modificación global llega con la ley de Beneficencia de $1849^{16}$.

Es un momento histórico de dependencia económica de las insitituciones privadas respecto al Estado, y ello dará lugar a las leyes desamortizadoras de 1855 , que sirven de control e intervención estatal respecto alas instituciones privadas de beneficencia ${ }^{17}$.

El clero regular fue perseguido, hubo matanzas y casi queda prácticamente disuelto. Pero, sobre todo debemos resaltar, como así lo hemos estudiado en apartados anteriores, que de todas las medidas gubernamentales, la demás trascendencia es la desamortización de los bienes eclesiásticos de 1836, bajo Mendizábal.

A partir de estos momentos el clero quedó privado de autonomía económica, lo que repercutirá en su bajo nivel intelectual, en su reclutamiento, a partir de entonces casi exclusivamente campesino, en la falta de envergadura de sus iniciativas, en su hostilidad al poder civil; y en su invencible desconfianza hacia el derecho nuevo. La política religiosa de las regencias borró en el clero los rasgos regalistas e ilustrados heredados del siglo XVIII y contribuyó a darle una fisonomía que perdurará hasta la guerra de 1936-39 ${ }^{18}$.

Con la firma del Concordato de 1851, renacen las Órdenes religiosas y se nota un florecer religioso en los sectores de cultura y grupos sociales, de los cuales nos ocuparemos más adelante. Sólo nombrar algunos ejemplos como referencia: destacan las notables misiones populares, tanto habladas como escritas (folletos, libros de devoción, etc...), llevada a cabo por san Antonio María Claret, así como las iniciativas de santa María Torres Acosta, fundadora de las Siervas de María, santa María Micaela del Santísimo Sacramento, fundadora de las Adoratrices. Se introducen en España las Conferencias de san Vicente de Paúl, traídas de Francia por Santiago Masarnau.

Es también, la época más brillante de los apologistas seglares como Juan Donoso Cortés y José María Cuadrado. Surgen, sin embargo, en este período un intento de secularizar el pensamiento español importando corrientes filosóficas traspirenaicas como el Krasuismo, etc... ${ }^{19}$.

\footnotetext{
${ }^{16}$ Estas normas con las que el gobierno moderado trataba de establecer un sistema jerárquico y centralizado de control social, sin que eso implicase un compromiso para el Estado. Esta ley su reglamento establecía una división entre establecimientos públicos y privados. De todas formas, no acaba con el proceso secularizador, ya que junto a la público, seguía contando con la iniciativa privada, y en concreto con la Iglesia católica en este ámbito benéfico asistencial. Habia, ciertamente, una Junta General, que residía en Madrid, pero se descentralizaba, pues, se contaba con la municipalización, las juntas provinciales, las de barrio, parroquiales o las d señoras.

${ }^{17} \mathrm{Cfr}$. Remitimos algunos estudios, entre los que destacamos el de Susín Betrán, Alonso Seco, Bernardo Gonzalo, Castro Alfín, etc... en obras citadas en este artículo.

${ }^{18}$ Cfr. GutiérRez NiETo, R., "Historia de la Iglesia» en Gran Enciclopedia Rialp, T. IX, Ed. Rialp, Madrid, 1972, pág. 81.

${ }^{19}$ Cfr. Gutiérrez Nieto, R., o.c. pág. 81
} 


\section{LA IGLESIA Y LOS POBRES: LA SOCIEDAD ESPAÑOLA DEL SIGLO XIX}

Decíamos que dependiendo de qué entendiésemos por pobres y pobreza, de igual modo responderíamos al problema.

Hemos visto el panorama y la realidad histórico-contextual donde se desarrollan los acontecimientos para poder ejercer desde ella y dar soluciones a los problemas planteados. Pues, el ser humano es hijo del momento histórico que vive, y como dice Julián Marías, "la historia significa la primera necesidad, porque su ignorancia impide saber dónde se está, de dónde se viene, quién se es y a dónde se va» ${ }^{20}$.

Es el momento, por tanto, de adentrarnos de lleno en el ámbito social y conocer de plano cómo la Iglesia desde su realidad histórica (sociedad del siglo $\mathrm{XIX}$ ) entendió y respondió al problema de la pobreza y a su vez, comprobar cómo caminaron, a veces a la par, juntos otras y en paralelo las más de las veces, la Iglesia (sociedad cristiana) y el estado (sociedad secular o laical).

Queremos, ahora, adentrarnos en el estudio sobre la teología de los pobres, analizar, qué idea, qué postura y cuál fue la capacidad de respuesta de la Iglesia española durante la primera mitad del siglo XIX ante el problema de la pobreza.

En definitiva, comprobar el paso que paulatiunamente se fue dando de una caridad cristiana a una beneficencia estatal.

\section{CONCEPTO DE POBRE-POBREZA, CARIDAD Y BENEFICENCIA}

Desde el punto de vista etimológico el término pobre, del latín pauperpauperis tiene el sentido o significado de necesitado, menesteroso y falto de lo necesario para vivir o que lo tiene con mucha escasez ${ }^{21}$. Así mismo, podemos aplicar otras acepciones que desde otros campos nos pueden ampliar el significado de pobre. Podemos por tanto, ver en el pobre, al humilde, al modesto de poco valor o entidad, al desdichado, infeliz y al triste. Al pobre de espíritu, aquél que mira con absoluto menosprecio los bienes y honores de este mundo, al pobre de solemnidad, de notoriedad, al pobre que no puede pedir limosna de puerta en puerta por su calidad y obligaciones y lo hace con el mayor secreto posible. Este sería el pobre vergonzante. También, debemos resaltar al pobre voluntario que se enajena voluntariamente de todo lo que posee, como hacen los religiosos con el voto de pobreza. $O$ al pobre soberbio que teniendo necesidad de auxilio o socorro, procura ocultarla no

${ }^{20} \mathrm{Cfr}$. Alonso SeCo, J. M"a., "La asistencia social y los servicios sociales en España», en Estudios Jurídicos, Serie Derecho Público, BOE, 1997, pag. 23.

${ }^{21}$ Cfr. Enciclipedia Universal llustrada. Concepto pobre. Ed. Espasa-Calpe, Madrid, 1964, pág. 978 
admitiéndolo, o el que no se contenta con lo que le dan o con el favor que le hacen, creyéndose merecedor de más ${ }^{22}$.

En primer lugar, comenzaremos analizando qué entiende la Iglesia por estos dos conceptos, caridad y beneficencia.

La posesión de los bienes por algunos, y la no posesión por parte de muchos, tuvo hasta tiempos relativamente recientes en la opinión popular un cierto carácter de fatalidad. Se nacía rico y se vivía rico; se nacía pobre y se vivía pobre. La Iglesia respondía con caridad ${ }^{23}$.

La existencia del pobre llegó a considerarse como un don de Dios al rico, a quien se ofrecía con ello la ocasión de ejercer actos de caridad; la exaltación de la limosna ha tenido con frecuencia este sentido. No se pretendía saber, por qué causa el rico era rico y el pobre era pobre; si esto era un derecho o debía considerarse como un abuso o simplemente una usurpación del trabajo del pobre.

Una vez más, hemos de tener en consideración que es muy difícil precisar estos tres conceptos, pues están sujetos a variables de tiempo y espacio. Es difícil establecer un módulo de pobreza que nos sirva para definir el hombre pobre.

La doctrina de la Iglesia sobre beneficencia y caridad se fundamenta básicamente en tres sólidos pilares. El primero de ellos se ajusta plenamente al mensaje evangélico como regulador y orientador de la conciencia cristiana: ... «haspes eram et collegistis me; nudus et couperuistis me; infirmus et visitatis me; in carcere eram et venistis ad me... Amen dico vobis, quamdiu fecistis uni ex his fratibus meis minimis, mihi fecistis ${ }^{24}$.

En esta misma línea conviene recordar cómo el sermón de las «Bienaventuranzas» se puede considerar como el código ideal de la perfección comportamental cristiana, como el programa doctrinal de los más altos saberes, como la más sugerente invitación para algunos y el mandato más exigente del amor al hombre sobre los cristianos creyentes.

En segundo término, la tradición y práctica histórica de la Iglesia española en el terreno de la caridad y beneficencia es el marco de referencia para seguir pensando, en el siglo XIX, que este ejercicio del amor cristiano está en las raíces de la identidad evangélica y ecumenista de la Iglesia.

En tercer lugar y como apoyo motivador para encontrarse en la primera línea de acción, la Iglesia en España mantiene la conciencia cierta de que

\footnotetext{
${ }^{22}$ Estas acepciones de la palabra pobre se pueden consultar en la Enciclopedia Universal llustrada que hemos citado anteriormente en las páginas 978 y 979 .

${ }^{23}$ Cfr. ARimón, G., La pobreza en el umbral de la teología. Ed. Estela, Barcelona, 1967, pág. 16.

${ }^{24}$ Este es el mensaje que encontramos en el evangelio de Mateo 25, 36-41 (era mendigo y me recogisteis, estaba desnudo y me vestisteis, enfermo y me visitasteis, estaba en la cárcel y fuisteis a verme... Os digo ciertamente que cuando hicisteis esto con uno de mis pequeños hermanos, lo hicisteis conmigo).
} 
su preparación es altamente cualificada, que la estructura de sus organizaciones e instrumentación de medios es suficiente y que la disponibilidad de sus miembros está garantizada. A pesar de los contratiempos de la primera mitad del siglo XIX para la autonomía económica de la Iglesia, como resultaron ser los períodos desamortizadores $(1835,1853$ y 1868) y la supresión del diezmo eclesiástico $(1837)^{25}$, la Iglesia participa en los programas de acción propuestos por el Estado, no como propietaria o distribuidora de bienes, sino como colaboradora a través de las instituciones religiosas y seculares, alargando manos y corazón en una tarea que siempre tuvo y tendrá un fuerte componente de caridad y entrega evangélicas. Esta conciencia y convencimiento de su capacidad se fundamenta en el sello marcado de la continuidad histórica y la posibilidad de adoptar nuevas formas de aportación.

\section{ACEPCIONES DE LA POBREZA}

Para la mejor comprensión de los términos que usamos, pauperismo, pobre, pobreza, como ya hemos ido indicando no debe buscarse en ellos una precisa terminología, tipología, o matizaciones de concepto metodológico. Haremos mención de un conjunto léxico que hace referencia a un amplio campo semántico que usaremos a veces con significado diferente y a veces con carácter sinónimo. Por ejemplo, pobre, necesitado, indigente se refieren a carencias económicas, y mendigo, pordiosero, etc... a formas de pedir para ir sobreviviendo.

Como puede fácilmente inferirse, el concepto de pobreza, globalmente entendido es móvil cuando se le quiere aplicar a una sociedad concreta, incluso cuando se quieren fijar unos umbrales económicos. Movilidad que se extiende a las sociedades, a los oficios, a los lugares, a los defectos, a los delitos, a la legislación, a la estructura económica de cada circunstancia concreta. El concepto no es nítido, se solapa con aspectos colaterales, que a veces, le son consustanciales, con otros elementos extraños, se tiñe de los objetivos de quien establezca la clasificación con unos determinados intereses económicos, políticos, religiosos o mentales ${ }^{26}$.

Ciertamente, que el concepto de pobre tiene un origen netamente religioso, cargado de sentido teológico, espiritual y moral.

La noción extrae de su fondo religioso una coherencia que le hace útil para el estudio de las representaciones y actitudes colectivas, aunque luego sea difícil asignarle un contenido social estable y preciso $^{27}$. Pero fue notorio

${ }^{25}$ Cfr. Sanz de Diego, R., "La Iglesia española ante el reto de la Restauración», R. García Villoslada (dir), Historia de la lglesia en España, vol. V. Ed. BAC, 1979, pág. 573.

${ }^{26}$ Carasa Soto, P., Pauperismo y revolución burguesa (Burgos, 1750-1900). Ed. Universidad de Valladolid. Secretariado de Publicaciones. Valladilid, 1987, pág. 30

${ }^{27}$ Mollat, M., Etudes sur I histoire de la pauvreté (Moyen Age-XVI siècle). París, 1974, pág. 89. 
su perfil teológico: el rico representa el poder de Dios Padre, el pobre el Verbo Encarnado, humillado y asimilado a la condición humana, el pobre es un instrumento de salvación, un intermediario entre Dios y el rico. Son dos imágenes del dogma que se traspasan a la moral: el pobre practica las virtudes de la humildad y de la resignación para alcanzar la imagen de Cristo y el rico ejercita la caridad junto con la advertencia de la inestabilidad de las cosas humanas. Imágenes que también se reproducen en la espiritualidad bifurcada en los dos caminos ascético y místico de acceso a Dios. Esta honda dualidad religiosa está transportada a la defensa del esquema social estamental. Ambas figuras están y permitidas por Dios y no conviene transmutar los papeles, sino conservar el orden social establecido y aprovecharlo como medio de salvación; el rico confórmese con su riqueza y practique la caridad y el pobre acepte su indigencia y humildad ${ }^{28}$.

Moral y jurídicamente la pobreza ha sido calificada alternativamente en sus diversas manifestaciones como positiva o negativa, según las coordenadas y las pautas vigentes en cada momento histórico: desde el enaltecimiento del pobre solemne, rodeado de protección jurídica para practicar legalmente la mendicidad y con título socio-religioso suficiente para demandar ayuda, hasta su persecución, encerramiento y represión, en función de unos intereses económicos-políticos imperantes.

Políticamente la pobreza ha sido utilizada como medio de prestigiarse con una acción caritativa, o como riesgo y amenaza contra la estabilidad de unos valores fundamentales como el Estado, el domicilio, la familia, el orden público, que imponen en cada momento los propios grupos dominantes.

Económicamente ha oscilado su valoración desde la consideración del mal menor, indispensable para que las jerarquías sociales y económicas ineludibles subsistan, pasando por la visión de pobreza como resultado de una ociosidad e inutilidad perjudicial al bien utilitario del Estado, para llegar al concepto de pobreza como producto de una injusta y desequilibrada distribución de los recursos económicos que enfrenta intereses contrapuestos ${ }^{29}$.

Culturalmente, la pobreza llegó a configurar un mundo autónomo con su lenguaje, su literatura, su estética, su simbología y su propia ética, muy consciente de sus instrumentos de expresión y sus recursos sociales.

Pero aún hay más. En el siglo XIX la imagen del pobre cambió radicalmente de forma que dentro del orden social que ocupaba, empezó a considerársele como elemento molesto y más tarde como un verdadero peligro. Al mismo tiempo, la caridad dejó de ser cuestión de «buenas obras» para pasar a ser un problema social al que había de darse soluciones.

\footnotetext{
${ }^{28}$ Martínez Albiach, A., «Ética socio-religiosa de la España del siglo XVIIl», en Burguense, no 12 , (1971), pág. 303-305.

${ }^{29}$ CaRAsa Soto, P., Pauperismo y revolución burguesa (Burgos, 1750-1900), Ed. Universidad de Valladolid, Secretariado de Publicaciones, Valladolid, 1987, pág. 31.
} 
Así, fueron surgiendo nuevas concepciones sobre el mendigo y la beneficencia, relacionándolas con el contexto político-social, sobre todo en varios momentos importantes de este siglo, como fueron el trienio liberal, las desamortizaciones, tanto de 1837, como la de 1853, y tras el movimiento obrero organizado a partir de 1868.

\section{CAUSAS Y FACTORES DE DETERIORO QUE CONDUCEN HACIA LA POBREZA}

Son varios los factores que influyen en el problema de la pobreza en la España del siglo XIX. Hay una continuidad, en términos generales, del Antiguo Régimen en los primeros años de este siglo.

Es una continuación un tanto artificiosa bajo el reinado de Fernando VII en lo que concierne a la asistencia social ${ }^{30}$. De todas formas la mayor novedad es el agravamiento de la situación que experimenta España sobre todo a principios de siglo.

Destacamos algunos de los factores que deterioran y determinan el empeoramiento de las condiciones de vida que producen y causan una gran masa de pobres y desposeídos.

1. La crisis económica que se arrastra del siglo anterior. Circunstancia que no ayudó a paliar el pauperismo y la creciente pobreza y aumento de pobres en España. Pues, la industrialización que en otros países dio trabajo y medios de subsistencia a muchos ciudadanos, no cumplió en España esta función con su implantación tardía. Con lo que un alto porcentaje del potencial humano excedentario hubo de vivir míseramente.

2. Además, hay otros elementos como la quiebra de las industrias de manufacturas y el colapso del tráfico mercantil, la crisis de la protoindustrialización, las transformaciones en los sistemas agrarios.

${ }^{30}$ Es menester recordar a modo de aclaración que a través de nuestro trabajo aunque usemos, a veces, indistintamente los términos de caridad (cristiana), beneficencia y asistencia social, creemos necesario precisarlos y matizarlos. Por caridad se entiende, ateniéndonos al evangelio, la actuación llevada a cabo por el individuo espontáneamente, es decir, voluntariamente, a fin de satisfacer las necesidades fundamentales de la vida humana que él descubre o encuentra en otro. Se distingue, pues, de la filantropía, que es hacer el bien por el bien. La caridad es un mandato divino, se considera una virtud que perfecciona al ser humano, es una virtud teologal. La beneficencia, como la palabra indica es hacer el bien a los demás. Pero, así, la pura acción individual de la caridad se va institucionalizando, se le va dando formas nuevas, cauces orgánicos y luego incluso jurídicos, como tendremos ocasión de desarrollar. $Y$ con el tránsito del Estado liberal al Estado social aparece el concepto de Asistencia social. Se comenzó a hablar de Asistencia social, con el nombre de ayuda pública en la Declaración de los Derechos del Hombre y del Ciudadano en 1971, y más claramente después de la Revolución del 1848. Entendemos, pues, por Asistencia social una actividad de carácter público, financiada con cargo a ingresos públicos. 
2. Crecimiento demográfico ${ }^{31}$ iniciado en España a mediados del siglo XVIII (básicamente debido a la drástica reducción de los írdices de mortalidad), y sostenido prácticamente hasta nuestros días, dio en el siglo XIX un incremento de la población.

Con la explosión demográfica hay un fuerte aumento de la población y un hacinamiento que se produce en las ciudades

3. La guerra de Independencia contra Napoleón viene a generalizar y a aumentar la pobreza. Son años de luchas, destrucciones y muertes que suponen la inutilización del instrumental productivo, el abandono de campos y cultivos, la destrucción y ruina de instalaciones asistenciales y las pérdidas de vidas humanas.

En definitiva, se nos presenta un panorama de extendida y generalizada menesterosidad, tanto estructural como coyuntural, dentro de una sociedad apocada, hundida por sus propias calamidades presentes y del inmediato pasado y la rigidez del orden político establecido. Tal es el basamento, prolongado más de medio siglo, en el que vendrán a repercutir los efectos pauperizadores de una industrialización tardía, débil y fragmentaria ${ }^{32}$.

Todo ello trae consigo, que un alto porcentaje del potencial humano excedentario hubo de vivir miserablemente, emigrando o sufriendo las penalidades como consecuencia de las guerras: hambres, enfermedades..., que llenan de pobres y mendigos las ciudades que llegan buscando los recursos que pueblos y villas no pueden ofrecerle. Y uno de los medios, casi el único que la ciudad cuenta para paliar el hombre a la cantidad de pordioseros, mendigos, desocupados, quincalleros, etc... llegados de todas partes, sobre todo a Madrid y a las ciudades litorales, (es de tener en cuenta que el clima de éstas ciudades es favorable para la habitabilidad), es la sopa conventual y la acción de algunas cofradías religiosas ${ }^{33}$.

Todos ellos engrasarán paulatinamente en el sector social de la marginación que será objeto, como veremos más adelante, de las preocupaciones, temores y atenciones consecuentes de los poderes públicos, dado que a diferencia de tiempos anteriores, apenas si les alcanzaba la caridad eclesiástica, cebándose en ellos la miseria y la mortalidad ante la ausencia de higiene, falta de alimentación, vestido y la ausencia de protección sanitaria.

${ }^{31}$ La población crece, aproximadamente, de 10 millones y medio de habitantes en 1797 a 12 millones en 1833 , y de dieciseis millones y medio en 1877 , lo que representa un aumento del $16 \%$, equivalente a un 0,44\% anual. (Cfr. Castro Altín, D., Las necesidades sociales y su cobertura: 1800-1868, en Historia de la acción social pública en España. Beneficencia y previsión Ed. Centro de Publicaciones Ministerio de Trabajo y Seguridad Social, Madrid, 1990).

${ }^{32}$ Cfr. Castro Alfin, D., o.c. pág. 70.

${ }^{33}$ Una de ellas era la Hermandad del Refugio, más conocida como la ronda del pan y huevo, que recogía a enfermos indigentes y los acomodaba, si era posible, en establecimientos de caridad, y algunas iniciativas de carácter filantrópico (Cfr. ASEM, A/59 Libro de acuerdos de la comisión de comidas económicas; Leg. 181, 183, 185, 189 y 192. Citado en Castro Alfin, D., o.c. pág. 71.) 
Como hemos visto ante el incremento demográfico y ante una economía deficitaria y las insuficiencias para dar una respuesta a la pobreza ${ }^{34}$ se buscan y van apareciendo nuevas concepciones acerca de la responsabilidades públicas respecto a los grupos marginales, tradicionalmente atendidos por iniciativa privada y clerical bajo el impulso del deber de caridad.

La Iglesia católica se da cuenta, de que ante la nueva problemática, ante la miseria social, la caridad no podía auxiliar sino a un corto número de individuos $^{35}$. La práctica de la caridad disminuye debido a los factores que ya hemos apuntado, pero a destacar la merma de recursos debido a las desamortizaciones y esquilmaciones a la que se ve sometida, y a la acumulación de las riquezas en pocos individuos con lo que se ve privada de recursos que a ella se destinan.

De todas formas, encontramos posiciones diversas, pues, según Pérez Pujol, al referirse a la necesidad de atenuar los males de la penuria económica, se pregunta si ello compete al Estado, al individuo o a la sociedad ${ }^{36}$.

Por su parte, Rafael Sociats, escribía que: «Todo lo que la caridad puede conseguir, es mitigar ciertos males del momento; entretener los de carácter permanente y el pauperismo, puesto que es un hecho incontrastable que, gastando valores considerables en socorros de todo género, existen en la sociedad clases enteras que viven sometidas a la perpetua indigencia ${ }^{37}$.

${ }^{34}$ Junto a los elementos socio-económicos que contribuyeron a las desigualdades sociales debemos ratificar aquí que este sistema asistencial se vio agravado con la herencia dejada por las luchas Napoleónicas y las desamortizaciones que ya hemos estudiado en este capítulo. Todo esto delataba la insuficiencia de los intentos reformadores de los ilustrados en el campo de la pobreza y la mendicidad y al mismo tiempo reclamaba una nueva forma de afrontar este problema de acuerdo con el talante propio de la clase social en auge, la burguesía.

${ }_{35}$ «Por ley natural, todo hombre tiene derecho a la vida, $y$, por consiguiente, también a la conservación de ésta. Si la organización social le impide utilizar sus fuerzas físicas e intelectuales para ganar su subsistencia, cosa que puede ocurrir por la cesación del trabajo, por la apropiación de todos los medios de producción y de todos los objetos de consumo, la sociedad tiene entonces el indiscutible deber de cuidar de estos desgraciados, bien procurándoles trabajo, bien por medio de la beneficencia” (Cfr. Scheicher, J., La Iglesia y la cuestión social, Ed. Librería Madrid, 1903, pág. 220

${ }^{36}$ "la beneficencia individualmente ejercida es superior a todas, porque siendo la caridad misma, es eficaz, discreta y digna. Sin humillar al pobre, sin dar espectáculo su miseria vergonzante, le ayuda en proporción a sus necesidades, le sostiene, io impulsa para encontrar en el trabajo los medios para vivir por si mismo, volviéndole a la sociedad como miembro útil. Por el contrario, la limosna pública, perdido el rubor, saboreadas las dulzuras de la pereza, le acostumbraría al ocio de la mendicidad. La beneficencia social, pero todavia particular, aunque no tan discreta y reservada, suple la insuficiencia de la individual, a la que se acerca mucho cuando es domiciliaria, y lleva ventajas a la del Estado; pero todas son necesarias, porque aunque todas ellas no bastan a dar pan para tantas bocas como abre de continuo el hambre» (Cfr. Pérez Pujol, E., La cuestión social en Valencia, Valencia, 1872, pág,23ss.).

${ }^{37} \mathrm{Cfr}$. Sociats, R., La indigencia en las ciudades y su mejoramiento por la beneficencia pública, lpm. de Manuel Alufre, Valencia, 1887, pág. 83. 


\section{LA DESACRALIZACIÓN Y RACIONALIZACIÓN DE LA POBREZA: DE LA CARIDAD CRISTIANA A LA BENEFICENCIA ESTATAL. EL LARGO PROCESO DE SECULARIZACIÓN}

La Iglesia fue perdiendo la primacía en lo que hemos dado en llamar, hasta este momento, "cuestión social», respecto a la concepción y trato que dispensó con respecto a los pobres y la pobreza a lo largo de su historia, para dejar paso, en este siglo decimonónico, a que el protagonismo recaiga en manos del Estado o poderes públicos, o sea, a la beneficencia estatal o asistencia social.

A principios del siglo XIX, la Iglesia hereda del Antiguo Régimen, todavía, poder y riqueza. A veces le preocupaba más el prestigio y su relevancia social que su autenticidad y testimonio evangélico ${ }^{38}$.

El problema social fue la gran cuestión del siglo XIX. Es un momento en que la Iglesia está abocada a la pobreza, en que el clero ha quedado económicamente igualado a las clases populares y pobres del país, sufriendo las mismas desdichas y desventuras. Parecía llegado el momento de conseguir una fusión estrechísima entre la gran masa de los desheredados y la Iglesia. Pero, el liberalismo, aunque empobreció a la Iglesia y frustró las aspiraciones de los desheredados, lo que hizo fue consumar el proceso secu-

${ }^{38}$ Destacan ciertas peculiaridades de la Iglesia en las primeras décadas del siglo XIX: existe un clero numeroso, pues, según el cerıso de 1797 había 61.752 eclesiásticos seculares, 49.365 religiosos y 24.007 monjas, que habitan en 2.051 y 1075 conventos respectivamente (Cfr. Sáenz Marín, J., Datos sobre la lglesia española contemporánea, 1768-1868, Madrid, 1975). Una Iglesia rica, pues, la renta producida por la propiedad eclesiástica en 1803 alcanza una vigésima parte de la renta territorial de España (Cfr. Moreau de Jones, Estadística de España, Barcelona, 1835, pág. 156 y ss), cantidad que se engrosa con la percepción de diezmos, las ofertas de los fieles y los estipendios de misas y funciones litúrgicas. Pero, también es verdad que esta riqueza quedaba notablemente disminuida por las contribuciones al Estado (tercias, excusado, noveno, séptimo eclesiástico, subsidio, etc...) y por la crisis agrícola que afectó a las comunidades propietarias.

Pero, a pesar de todo ello, la Iglesia sigue manteniendo por sus propios medios seminarios, y numerosos establecimientos de enseñanza y de beneficencia, como tendremos ocasión de comprobar a lo largo de nuestro trabajo. Por ejemplo, el Estado pidió colaboración a los religiosos de ambos sexos para que abrieran escuelas, colegios de primera letras (Cfr. Decretos de 19-XI-1815 y 8-VII-1816); se sigue despachando la comida a los pobres en las porterías de los conventos, la llamada «sopa boba»; ejemplos de prelados, como el obispo de Pamplona Uriz y Lasaga ( Cfr. Goñi Gaztambide, J., el obispo de la caridad, 1815-1829, en «Príncipe de Viana», 28, (1967), pág. 353-440), o el arzobispo de Sevilla Cienfuegos, hicieron grandes limosnas a instituciones de caridad. La relativa hoigura económica que, a pesar de la crisis, disfrutaban los establecimientos eclesiásticos, hacía todavía posible la continuidad de una caridad institucionalizada. Y un pueblo masivamente católico donde las manifestaciones de la piedad revisten unos caracteres altamente populares, externos y multitudinarios. La vida pública estaba empapada de sentimientos religiosos; las ciudades estaban repletas se signos religiosos; los legos mendicantes llenaban su alforja con las limosnas obtenidas en los mercados; al anochecer se extendía el lúgubre toque de ánimas y un hombre salía con una linterna a pedir limosnas por los difuntos; en Madrid, por ejemplo, se ejercían, como también se hacía en otras ciudades, ciertas actividades nocturnas, como la Santa Hermandad de Nuestra Señora del Refugio, que enviaba a un sacerdote y dos seglares a recorrer los cuarteles de los barrios para recoger a los hambrientos, enfermos o expósitos, o la Hermandad de María Santísima de la Esperanza, llamada «del pecado mortal», que pedía limosnas para decir misas por la conversión de los pecadores. Así lo recuerda Blanco, que veía como costumbre general esto en España (Cfr. Whtite, B., Cartas españolas, Madrid, 1970, pág. 147). Ejemplo, de este fervor del momento y responsabilidad 
larizador, racionalizando y desacralizando lo que ya se iba gestando siglos antes, como el XVI, XVII y sobre todo en el XVIII con las nuevas ideas aportadas del movimiento de la llustración.

\section{TRATAMIENTO Y MEDIDAS PARA LA ERRADICACIÓN DE LA POBREZA}

Ante tal situación se intentó tomar medidas y sobre todo clarificar quiénes eran los verdaderos pobres, sujetos de ayuda y socorro de la pobreza y quiénes eran los falsos pobres, a los que se les debía perseguir, corregir y reprimir.

Es una nueva etapa en la que entran en juego diversas concepciones de la pobreza, como ya hemos tenido ocasión de comprobar. Surgen realidades nuevas, aumento de la demografía; es la etapa de la creciente industria; aparecen ideas nuevas como el liberalismo y clases sociales dominantes como la burguesía, que aprovechará esta circunstancia y que tendrá en el pauperismo un instrumento en sus manos que intentará sacarle partido; nace la figura del obrero o proletario, o sea, una nueva forma de concebir el trabajo; se dan respuestas como veremos al pauperismo desde instituciones sociales y eclesiales a través de la enseñanza, un nuevo tratamiento y preocupación de la salud a través de un mejoramiento higiénico.

Lógicamente, no surgen los hechos de un día para otro y esos problemas o respuestas se van gestando a lo largo del tiempo como un proceso lento y costoso.

Ya hemos mencionado cómo hasta la terminología debemos precisarla o por lo menos tenerla en cuenta, para tener presente al menos su significado más real o al menos el más adecuado que nos ofrece cada momento histórico.

«Acción social» o asistencia social son expresiones más recientes, más jóvenes. Pues, antiguamente, se hablaba sólo de caridad o beneficencia.

\section{LA POBREZA COMO PROBLEMA SOCIAL}

Con la revolución industrial y los consiguientes cambios sociales, la problemática de la pobreza adquirió una nueva dimensión, que ya no se podía contemplar desde la doctrina tradicional de la Iglesia y de la que no se tomó conciencia hasta más tarde.

Con la desintegración del estratificado orden estamental de la Edad Media y la aparición de un proletariado de obreros industriales, se tomó conciencia de que la pobreza de grupos y clases enteras de la población depende de unas condiciones sociales y políticas que no pueden aceptarse sin más como un orden natural o incluso querido por Dios, sino que han sido 
establecidas por los hombres y, consiguientemente, pueden ser modificadas políticamente $y$, por lo tanto, se hallan enmarcadas en el ámbito de la responsabilidad colectiva.

De este modo, el contraste entre la pobreza y la riqueza, o los pobres y los ricos aparece como auténtica cuestión social que, muy difícilmente puede resolverse mediante la caridad tradicional, o la beneficencia individual, sino mediante reformas sociales 0 , incluso, mediante un cambio revolucionario de la sociedad.

Por lo que, visto el panorama al que nos vamos remitir, va a ser muy difícil que este problema tenga fácil o ninguna solución desde el punto de vista que ha ofrecido la tradición a cerca, tanto de la visión de la pobreza, como de los medios que puso a su alcance para acabar con ella.

\section{LA POBREZA EN EL SIGLO XIX. LA CONCEPCIÓN LIBERAL DE LA POBREZA: EL AUGE DE LA BURGUESIA}

Nos encontramos en el momento histórico llamado la Revolución Industrial, pues, a partir de la segunda mitad del siglo XVIII se considera como una línea divisoria que es fundamental para la historia de la humanidad. Permitió a la sociedad la producción de un flujo permanente de bienes y su distribución a una comunidad en continuo crecimiento. Hubo un crecimiento económico acumulativo y en consecuencia, el incremento de la riqueza material estuvieron dentro de lo posible ${ }^{39}$.

El concepto de pobreza en el siglo XIX está modulado por la ideología burguesa, la clasificación que de ella se hace por parte de la burguesía decimonónica tiende a mediatizar este problema en beneficio de su modelo social, el tratamiento y asistencia que la beneficencia liberal hace de la pobreza es un instrumento más que la burguesía utiliza para llevar a cabo su revolución y control social ${ }^{40}$.

El liberalismo surge como rebelión de la sociedad contra el Estado Absolutista del Antiguo Régimen. Y se caracteriza por tener una concepción individualista según el cual los valores individuales son superiores a los colectivos.

Pero, como afirma García-Pelayo, el liberalismo decimonónico no se fundamenta en un individualismo concreto o vital, sino en un individualismo abstracto, que concibe a los individuos no en un aspecto singular, sino en el genérico, de donde se deduce su igualdad y homogeneidad sustanciales y el derecho de que cada individuo tenga igual pretensión al despliegue de su

\footnotetext{
${ }^{39}$ Cfr. LIS, C., y Soly, H., Pobreza y capitalismo en la Europa preindustrial, Ed. Akal, Madrid, 1984, pág. 153.

${ }^{40}$ Cfr. Carasa Soto, P., «Metodología del estudio del pauperismo en el contexto de la revolución burguesa española, en CASTILLO, S., (coord) La historia social en España», Ed. Siglo XXI, Zaragoza, pág. 361.
} 
existencia y al deber de respetar dicha pretensión de los demás. El Estado Liberal tratará de cumplir esta finalidad mediante el reconocimiento solemne de un grupo de derechos individuales, mediante la garantía de la vigencia de tales derechos y la sumisión al principio de legalidad que elimine todo arbitrio peligroso para la seguridad de la esfera jurídica individual ${ }^{41}$.

Un primer reconocimiento de los derechos del individuo se produce en 1789 con la Revolución Francesa, que impone el deber de la Nación de proporcionar trabajo al necesitado y ayuda a quien no pudiese desempeñarlo, consagrando expresamente el derecho a la asistencia de los ciudadanos ${ }^{42}$.

La asistencia pública supondrá, tanto en el terreno ideológico, como en el político y en el práctico, una verdadera revolución en la concepción de los fines del Estado. Lo mismo ocurrirá en España a finales del siglo XVIII y principios del siglo XIX, aún cuando con menor intensidad respecto a Francia e Inglaterra, respecto a los procesos de estructuración laica y organización política de la beneficencia y asistencia social ${ }^{43}$.

En el Estado liberal, va a tener cabida y desarrollo la asistencia al indigente, que empezará a denominarse beneficencia, dentro de un contexto público, como servicio administrativo ${ }^{44}$, en el que se haga realidad la conocida frase de Montesquieu: "El Estado debe a todos los ciudadanos una subsistencia segura, el alimento, un vestido conveniente y un género de vida que no sea contrario a la salud ${ }^{45}$.

Vamos a comprobar la relación que hay en este siglo XIX del nacimiento de la beneficencia pública y su desarrollo con el régimen liberal, y cómo se va dando de una forma paulatina este paso de la caridad y beneficencia cristiana a la beneficencia estatal y laica.

Un hecho importante del liberalismo que propició la transición hacia la beneficencia pública es el de la desvinculación de mayorazgos y patronatos y el de la desamortización de bienes que estaban en poder de entidades eclesiásticas, municipales y demás manos privadas. Una y otra alcanzaron de lleno a los bienes de la beneficencia, especialmente de la privada ${ }^{46}$.

Hacemos un breve recordatorio, cómo la primera medida tomada por Godoy en 1798 declaró vendibles los bienes pertenecientes a hospitales, hospicios, casas de misericordia, de reclusión, cofradías y obras pías ${ }^{47}$. La Ley

${ }^{41}$ Cfr. García-Pelayo, M., Derecho constitucional comparado, 3 ed., Revista de Occidente, Madrid, 1953, pág. 143 y ss.

42 "El pobre, tiene derechos incontestables sobre la abundancia de los ricos» (Cfr. VENTURI, A., I fondamenti scientifici della Sicurezza Siciale, Milano, Dett. A. Guifré, 1954, pág. 31.

${ }^{43} \mathrm{Cfr}$. VICENS VIVES, J., Historia económica de España, 8ª ed. Barcelona, 1971, págs. 456 y ss.

${ }^{44}$ Cfr. Arias Miranda, J., Reseña histórica de la beneficencia española, Madrid, 1862, págs. 46-47.

${ }^{45}$ Cfr. Montesquieu, C., El Espíritu de las Leyes, lib. 23, cap. 29.

${ }^{46} \mathrm{Cfr}$. Alonso SECO, J. Ma ., Gonzalo González, B., La asistencia social y los servicios sociales en España, Estudios Jurídicos, Serie Derecho Público, Ed. BOE, Madrid, 1997, pág. 53.

${ }^{47}$ Cfr. Real Célula de 19 de septiembre de 1798, Novísima Recopilación, Ley XXII, tít. V, Lib. I. 
de septiembre de 1820 suprimió los mayorazgos y patronatos, y prohibió a iglesias, monasterios, hospicios, hospitales, casas de misericordia, y otros parecidos adquirir bienes raíces o inmuebles.

De todas formas, las desamortizaciones más radicales y que dejaron una huella más profunda se promulgaron entre 1836 y 1855 siendo ministros Mandizábal y Madoz respectivamente ${ }^{48}$.

\section{RESULTADOS Y CONCLUSIONES DE LA DESAMORTIACIÓN RESPECTO A LA BENEFICENCIA}

La desamortización se ejecutó mal. Si técnicamente tenía su razón de ser y socialmente se podía justificar, prácticamente fue llevada de modo injusto y discriminatorio, llegando a convertirse en una dilapidación de bienes, sin provecho alguno para el Estado. En lugar de ser una verdadera reforma agraria se convirtió en una transferencia de bienes de la Iglesia a las clases económicamente fuertes ${ }^{49}$.

Los resultados, pues, no fueron, ni mucho menos los esperados y apetecidos. Aunque no sería justo resaltar sus aspectos positivos. La propiedad quedó libre de aquella condición que inmovilizaba su circulación. Desaparecieron muchas tierras improductivas, pues los nuevos dueños quisieron que les rentase su inversión. La superficie de tierras cultivables aumento.

De todas formas, el balance se puede considerar como negativo, pues, desde el punto de vista hacendístico el Estado no hizo el negocio que esperaba. Ciertamente, quৎ la medida era necesaria, pero se llevó a cabo en un mal momento, con precipitación y de una forma que resultaron pocos los beneficiados.

Lo que sí le dio mejores resultados a Mendizábal con su programa fue en la consolidación del régimen liberal, pues los propietarios de las tierras desamortizadas fueron sus más firmes defensores del sistema que les había permitido la realización de tal negocio.

Uno de los frutos más amargos de la desamortización fue la consagración de la proletarización del campesinado ${ }^{50}$.

\footnotetext{
${ }^{43}$ No incluimos en este apartado el estudio de las amortizaciones y desamortizaciones. Haremos mención, mediante un resumen lo que concierne a la beneficencia.

${ }^{49} \mathrm{Cfr}$. UBIETO, A., Introducción a la historia de España, Barceriona, 1970, pág. 556.

${ }^{50}$ En palabras de Andrés Borrego recuerda «...el grave daño que iba a causar a los actuales colonos y arrendatarios de las tierras de los conventos, a quienes los nuevos dueños de las heredades les subirian los arriendos... no han pasado veinte dias... y nos llueven reclamaciones contra los compradores de bienes nacionales del tiempo de la Constitución, los que, apenas han recaudado la posesión de las fincas (cuyo pago en gran parte no han realizado), cuando han comenzado a desahuciar a los labradores y a difundir la alarma, el desconsuelo y la desolación por ese sinnúmero de pobres colonos, cuyos ascendientes vienen labrando de inmemorial las fincas de las comunidades religiosas». Cfr. ComELLAS, J.L. «Siglo $X I X »$, en Historia de España, Ed. Carroggio, Barcelona, 1982, pág. 140.
} 
La desamortización eclesiástica fue un expolio difícilmente justificable desde el punto de vista legal y moral.; en cuanto a la desvinculación de los beneficios nobiliarios y de los mayorazgos, el propietario no quedaba realmente obligado a nada.

En lo social tuvo grandes repercusiones, pues, la desamortización favoreció a los nuevos propietarios, los burgueses, que pudieron imponer a su gusto las condiciones de explotación y contrata. Se generalizó la formación de un proletariado campesino, jornaleros, braceros, yunteros, empobrecido y sin medios de defensa ${ }^{51}$.

Finalizamos este apartado dedicado a la desamortización con las palabras de los Sres. Moyano y Arias combatiendo el proyecto de Madoz, "...Ios cuales aseguraron que ya llegaría un día en que no se pagarían los valores dados en equivalencia de los bienes vendidos á la beneficencia, $y$ se lamentaban de lo que esto entibiaría la caridad..." y, por ello lamentan «...que en la desamortización de los bienes de beneficencia e intrucción no se haya aplicado algún lenitivo, y más aún habiéndolo hecho respecto de los de la lglesia»"52.

A causa de estas reformas, las funciones asistenciales que la Iglesia dejó de atender hubieron de ser dispensadas por las Administraciones Públicas a través de sus recursos presupuestarios, y el legislador tuvo que encomendar primero a los Ayuntamientos, y más tarde a Diputaciones Provinciales y al Estado, responsabilidades públicas en atención de los indigentes, como podemos comprobar a lo largo de nuestro estudio ${ }^{53}$.

\section{DE LA CARIDAD ECLESIAL A LA BENEFICENCIA ESTATAL: EL LARGO PROCESO DE LA SECULARIZACIÓN}

Es a partir del segundo tercio, cuando se generaliza, no sólo en España, sino en toda Europa, la concepción del Estado como valedor y sustento de los necesitados. Poco a poco se va dando la secularización social que como ya hemos ido adelantado procede fundamentalmente del desmantelamiento ideológico del Antiguo Régimen a través de la ideología llustrada y a través de la Revolución Francesa que comienza a sustituir el concepto y práctica caritativa por el principio de justicia y su aplicación social.

${ }^{57}$ Cfr. Comellas Garcia, J.L., Desamortización, o.c. pág. 554.

${ }^{52}$ Cfr. Hernández Iglesias, F., o.c., pág. 619

${ }^{53}$ A través de estas puntualizaciones que vamos haciendo nos vamos dando cuenta cómo se va dando el paso desde la caridad (cristiana), a un incipiente sistema público de protección asistencial que correrá a cargo, en un primer momento, de los poderes más concretos como municipios, juntas, etc, como ya hemos ido haciendo mención desde las primeras leyes sobre beneficencia $(1812,1822)$, para ir pasando la mayor carga de responsabilidad, posteriormente, al Estado, con la Junta General, las Diputaciones, etc... y las leyes de 1849 y el Reglamento de ejecución de 1852. 
Ello va tomando cuerpo y se plasma tanto en la mentalidad de la gente y sociedad como a través de las leyes, y va pasando esta obligación y responsabilidad al Estado como acción benéfica pública.

Aspecto importante por el que el Estado va tomando protagonismo es debido al problema económico creado a las tradicionales instituciones benéficas eclesiásticas por causa de la desamortización y por el creciente cada vez más del número de pobres a causa de las crisis económicas producidas a comienzos del siglo XIX.

El Estado asume, así, la organización benéfica por necesidad de organización y, también, como control de los pobres.

\section{UNA NUEVA VISIÓN: EL LIBERALISMOY YA REVOLUCIÓN BURGUESA, CLAVES PARA EL SIGLO XIX.}

El concepto de pobreza en el siglo XIX está modulado por la ideología burguesa, como matiza Soto Carasa «la burguesía decimonónica tiende a mediatizar este problema en beneficio de su modelo social, tratamiento $y$ asistencia que la beneficencia liberal hace de la pobreza, o sea, es un instrumento más que la burguesía utiliza para llevar a cabo su revolución, su dominio y su control social ${ }^{54}$.

Ya hemos comentado y hecho alusión de cómo el liberalismo surgió como una rebelión de la sociedad contra el estado absolutista del Antiguo Régimen. Preconiza los valores del individuo, sus derechos individuales afirmando la libertad garante que le ofrece el Estado. Derechos individuales de asistencia, de ayuda y de proporción de trabajo para el necesitado.

De todas formas, es importante y así lo vamos a reflejar a continuación, cómo se conjugan y se dan en consonancia los principios liberales que respetan la acción del individuo y de las asociaciones en que se agrupa, y que esta acción de beneficencia del Estado, pública, no relega por completo, y si lo hace, es sólo en parte, a la caridad, y en concreto a la caridad eclesial o cristiana $^{55}$.

Ciertamente, que los poderes públicos pretenden asumir lo que hasta el momento y secularmente había sido competencia de la Iglesia. Se crea, pues, polémica de protagonismo, que ahora es asumido por el Estado, relegando a un segundo plano a la Iglesia.

\footnotetext{
${ }^{54}$ Cfr. CaRAsa Soto, P., Metodología del estudio del pauperismo en el contexto de la revolución burguesa española, en La Historia Social en España, (coord. Santiago Castillo), actualidad y perspectivas, Ed. Siglo XXI, Zaragoza, 1990.

${ }_{55}$ Por ejemplo, la ley de Beneficencia de 1822, del Trienio Liberal, establece que las Juntas de beneficencia prefieran en lo posible las hermanas de la Caridad para desempeñar todos los cargos, y que se valgan al mismo efecto de asociaciones de caridad, religiosas o seglares..., procurando atraer a objetos de caridad las demás hermandades que hubiese en su distrito con distintos fines ( Cfr. Art. 14 y 15).
} 
Pero, también, debemos afirmar que la acción administrativa pública no va a suprimir la acción privada, o sea, que asume y cuenta con las fundaciones ya existentes con anterioridad. Lógico es que las necesita, pues en estos momentos no está preparado para asumir desde sí mismo todo el aparatoso y complejo mundo de beneficencia y asistencia que se necesita para la atención de las necesidades que surgen en el siglo XIX.

Hay pues, y de hecho se da, una combinación de caridad eclesial-cristiana, beneficencia privada y beneficencia pública-Estatal en lo que concierna a la asistencia social.

\section{BENEFICENCIA ECLESIAL Y BENEFICENCIA ESTATAL}

A pesar de la merma de autonomía y poder económico de la lglesia, de la que ya hemos comentado, sobre todo debido a la pérdida adquisitiva de medios que supuso la desamortización y la pérdida de protagonismo en los medios sociales, su presencia en el campo de la beneficencia sigue siendo notable. Así, lo expresa Maza Zorrilla ${ }^{56}$, cuando afirma "que la Iglesia española todavía popular y poderosa tiene clara conciencia de su identidad y especificas funciones: el culto, la asistencia social y la enseñanza»"57.

Además, de estas actividades específicas de la Iglesia, podemos añadir las ya seculares en las que el laicado participó con sus organizaciones gremiales, hermandades y cofradías o con donaciones particulares en la acción benéfica-caritativa.

Es significativo destacar esta participación de los laicos cristianos comprometidos y sobre todo la presencia de la mujer en estas tareas de asistencia, benéfico-caritativas a través de las congregaciones creadas con el exclusivo fin de ejercicio al servicio del pobre y menesteroso.

Igualmente merece destacar la presencia de la Iglesia en el campo de la enseñanza lo que supone una nueva adaptación a los nuevos tiempos en el ámbito de la beneficencia del siglo XIX en el que la Iglesia tiene una aportación valiosa y un enriquecimiento sobre los modelos tradicionales del ejercicio de la caridad entre los menos favorecidos).

${ }^{56}$ La burguesía tiene en sus manos la riqueza y el poder políticos; la Iglesia únicamente su tradición y algunos viejos aliados (nobleza). La actitud generalizada de la burguesía europea consiste en "pactar» con las fuerzas que aspira a derrotar. Cfr. MAZA ZORRILLA, E., La pobreza y asistencia social en España, siglos XVI al XX. Aproximación histórica, Ed. Secretariado de Publicaciones Universitarias de Valladolid, Valladolid, 1987, pág.115

${ }^{57}$ Cfr. Maza Zorrilla, E., o.c. pág. 114. 


\section{EL PAUPERISMO O LA CUESTIÓN SOCIAL (SIGLO XIX)}

Hemos venido remarcando y así queremos volver a expresarlo, por su transcendental importancia, los cambios que se han ido dando en España a lo largo del siglo XIX, y que se iban gestando ya anteriormente, siglo XVI y sobre todo, a finales del XVIII, relativo a la caridad cristiana y la beneficencia estatal, ya sea pública o privada, colectiva o individual.

Hemos afirmado ya que el problema social fue la gran cuestión del siglo $X I X$. Es un momento donde la Iglesia ha quedado lanzada a la pobreza ${ }^{58}$; en el que el clero asalariado ha quedado económicamente igualado a las clases pobres del país, sufriendo sus mismas desdichas y desventuras. Parecía el momento óptimo de conseguir una fusión estrecha entre la gran masa de los desheredados y la Iglesia. Con las ideas liberales y las medidas tomadas por el liberalismo, sobre todo, la con desamortización, la Iglesia había decaído económicamente, o sea, se había empobrecido, y los pobres no llegaron a conseguir las aspiraciones que les habían prometido los liberales, vieron pues, fracasadas sus aspiraciones.

\section{LA CARIDAD CRISTIANA Y EL SISTEMA BENÉFICO ASISTENCIAL DECIMONÓNICO}

Los ilustrados son precursores con relación a la concepción liberal de la pobreza. Por ello creemos necesario, tratar en este apartado cuál es la concepción de la pobreza en su evolución histórica, así como las consecuencias de ella derivadas para una mejor comprensión del tema que estamos tratando.

La concepción de la pobreza y de la asistencia liberal insiste en la dimensión social e individual, económica y política. Se presenta, pues, la beneficencia como un instrumento para defender la organización social de la burguesía o de oligarquías locales ${ }^{59}$. Y sigue comentando Carasa Soto que «se concibe la beneficencia como un escudo protector para el orden social... como un colchón amortiguador de las presiones sociales producidas por la acumulación de las riquezas y el poder en manos de estos grupos dominantes... pues, las clases pobres ponen en peligro los intereses económicos de las clases dirigentes, amenazan la propiedad, el orden público y los servicios urbanos necesarios para mantener el equilibrio social que los proteja...

${ }^{58}$ En la Iglesia al igual que en toda la sociedad se dan cambios cualitativos y cuantitativos. Como argumenta Sanz de Diego: "la española es una Iglesia encarnada y popular que irá experimentando dolorosamente el desenganche de la masa... Es un cuerpo con clara conciencia de su identidad y tarea: el culto, la beneficencia y la enseñanza... De benéfica y limosnera pasará la lglesia española a necesitada e indigente en ocasiones (Cfr. Sanz de Diego, R. $\mathrm{M}^{\mathrm{a}}$,, «La lglesia española y el reto de la industrialización", en Historia de la Iglesia en España, dir. Garcia Villoslada, R., Ed. B.A.C. Maior 20, Madrid, 1970).

${ }^{59}$ Cfr. Carasa Soto, P., Historia de la beneficencia en Castilla y León. Poder y pobreza en la sociedad castellana. Secretariado de Publicaciones Universidad de Valladolid., 1991, pág.14-15. 
y adelantamos una de las causas y de novedad que supone esta época liberal e industrial respecto a la de el Antiguo Régimen, pues, el pobre ya no solo será el que carece de propiedad como anteriormente, sino que será el que carece de trabajo como fuente de renta para vivir ${ }^{60}$

Así, pues, la pobreza y la asistencia deberán controlarse y centralizarse de forma que la beneficencia caiga bajo la órbita general estatal, bajo la influencia provincial intermedia, y bajo la esfera de actuación municipal, relegando y sustituyendo así el viejo papel eclesiástico pontificio, diocesano y parroquial que pautaba la antigua organización asistencial.

Estos son los pasos importantes que van dando paulatinamente haciendo recaer con mayor fuerza la responsabilidad de la atención al pobre en manos estatales. Es el avance del capitalismo que implica, por un lado, un incremento de la pobreza estructural, o sea, cada vez se incrementa el número de pobres permanentes, mendigos, y vagabundos; y por otro lado, como ya hemos adelantado anteriormente, se va consolidando un nuevo tipo de pobreza, ligada al mundo del trabajo y definible tanto por la miseria y precariedad de las condiciones de vida y de trabajo como por la constante inseguridad e incertidumbre ante el porvenir.

En principio, las instituciones y poderes públicos tratan de controlar la desaparición del aparato asistencial del Antiguo Régimen. y sustituirlo por otras instituciones benéficas y éstas complementadas con las iniciativas individuales.

\section{MEDIDAS TOMADAS DESDE LA CONCEPCIÓN LIBERAL: INTERVENCIONISMO ESTATAL, LAS BASES LEGALES DEL NUEVO RÉGIMEN}

El sistema ilustrado del siglo XVIII se va imponiendo al sistema tradicional o del Antiguo Régimen, en sus valores, y en su sistema de tratamiento de la pobreza. Ciertamente, lo iremos comprobando, que aunque se va imponiendo lentamente, nos atrevemos a decir que se dará más en un plano formal, que en la realidad misma.

La autoridad eclesiástica mantuvo una actitud defensiva frente a la intervención del Estado. Se le reconoce al Estado el derecho a intervenir en la controversia social. Es el caso del Cardenal Antolín Monescillo que ve en esta injerencia un cierto temor y miedo, por lo cual el quiere matizar y precisar al respecto sobre dicho asunto. El prelado acusa el temor de que la beneficencia oficial «matase los vuelos de la caridad" y los sustituyese por el "cálculo egoísta de la economía política», olvidando el principio de subsi-

${ }^{60}$ Cfr. Carasa Soto, P., o.c. pág. 15. 
diaridad: pues, lo propio del Estado era proteger las iniciativas privadas y eclesiásticas, no expulsar a la Iglesia del ámbito benéfico.

Lo cierto, y la realidad es, como veremos que la colaboración es mutua por ambas instituciones, y a veces cuanto menos la asumisión casi plena de la nueva asistencia social por la misma Iglesia e instituciones religiosas ${ }^{61}$.

De todas formas como podremos tener ocasión de comprobar es un proceso largo, duro, oscuro y bastante complejo.

Recordemos que este momento histórico es difícil para la Iglesia y, sobre todo respecto a las relaciones con el Estado. En ocasiones es humillada, perseguida y expoliada. Se cierran monasterios o son abandonados a la fuerza. Hechos transcendentales como la desamortización, la guerra de la Independencia, cuyas consecuencias son fatales para el país y la población que se ve sumida en la miseria y el hambre.

A la crisis económica, hay inestabilidad de los negocios,, levantamientos, guerras, revoluciones. Los precios suben, hay escasez de alimentos.

La Iglesia pasa por unos momentos difíciles, como ya hemos mencionado anteriormente, debido a los acontecimientos políticos, sociales, económi$\cos$ y medidas tomadas que la situaron a un segundo orden y prácticamente la desmantelaron en su conjunto humano, económico, etc... pues, queda relegada a ciertos ámbitos de la sociedad, como son el culto, la educación, la enseñanza, y en parte sigue, en la medida de sus pocas posibilidades practicando la beneficencia ${ }^{62}$.

Así mismo, ratifican esta situación estudios hechos al respecto como son los de Maza Zorillla cuando afirma ... "que frente al declive moral de la moral católica (ya no prima el más allá y la recompensa ultramundana), la moral burguesa, individualista, busca la felicidad en este mundo, aquí y ahora...» Entonces, nos preguntamos, ¿quién se encarga de toda esa inmensidad de pobres, miserables, vagabundos.... que como sabemos estaba plagada la España decinonónica? Y sigue argumentando Maza Zorrilla, que será la medicina «la que se comprometa a neutralizar los peligros sociales mediante el control de la higiene pública, vigilancia... represión...inspección...etc...63.

Pero, seguimos con el problema, pues, son los pobres y los menesterosos los que constituyen el gran grueso de la población, y aunque la Iglesia se ve relegada a segundo término, no se podrá prescindir ella, y sus instituciones tendrán que hacerse cargo de niños huérfanos,, expósitos, ancianos,

\footnotetext{
${ }^{61}$ Cfr. Sanz de Diego, R, M, Medio siglo de relaciones Iglesia-Estado. El Cardenal Antolín Monescillo y Viso (1811-1897), Publicaciones de la Universidad Pontificia de Comillas, Madrid 1979, pp. 383 y ss.

6a García de CoRTAZAR, F., Iglesia y sociedad en la España contemporánea, en Estudios sobre historia de España, U.I.M.P, Madrid 1981.

${ }^{69}$ MaZA Zorrilla, E., Pobreza y asistencia social en España, siglos XVI al XX. Aproximación histórica. Ed. Secretariado de Publicaciones, Universidad de Valladolid, 1987, págs. 114-119.
} 
etc... Pues, como dice Sanz de Diego «... ni se podía ni se debía prescindir de la colaboración de la Iglesia... los donantes, regularmente creyentes, tenían más confianza en la asistencia caritativa que en la oficial y orientaban sus aportaciones hacia aquélla a través de sus representantes" ${ }^{64}$.

Lo cual significa, y así lo hacemos entrever, que aunque a la Iglesia se le relega a segundo término, se le excluye de ciertas funciones estatales y de lugares de mando, o se le merma económicamente, parece ser que no es tanta la «cesura radical que a veces se ha puesto en este terreno, entre el Antiguo Régimen y el mundo liberal ${ }^{\star 65}$.

En definitiva, la tradicional beneficencia eclesiástica se va secularizando y estatalizando, o como otros autores consideran que a partir de las desamortizaciones ha sido un modo de controlar y un instrumento de inventariar los recursos de modo que así la beneficencia pasa no solo del ámbito religioso para insertarse en el medio civil, sino de la sujeción a los viejos intereses estamentales para integrarse en el libre juego socio-económico de las fuerzas dominantes ${ }^{66}$. Y lo que posteriormente se le denominó en «generales, provinciales, y municipales» ${ }^{67}$.

\section{ASISTENCIA SOCIAL, INTERVENCIÓN ESTATAL Y BASES LEGALES}

A principios del siglo XIX se había agravado, por las diversas causas que hemos mencionado, las condiciones de pobreza de la población, por lo que urgían una serie de reformas en el sistema asistencial.

${ }^{64}$ SANZ DE DIEGO, R M., "La Iglesia española ante el reto de la industrialización» en Historia de la lglesia española, B.A.C., Madrid 1979, t. V: La Iglesia en la España contemporánea, pp. 575 y ss.

${ }^{65}$ Cfr. Andrés Gallego, J., Pensamiento y acción social de la Iglesia en España, Ed. Espasa Calpe, Madrid 1984, págs. 39-40. Uno de los motivos que aduce el autor para apoyra su afirmación es la verdadera oleada de congregaciones e instituciones que surgen y nacen o renacen en esta época y en especial las femeninas.

${ }^{66}$ Cfr. Carasa Soto, P., Historia de la beneficencia en Castilla y León. Poder y pobreza en las sociedades castellanas. Ed. Secretariado de Publicaciones Universidad de Valladolid, Valladolid 1991, pág. 16-17.

${ }^{67}$ Hernández Iglesias cuando habla de la clasificación de la beneficencia en un segundo apartado dice: «como esta clasificación de la beneficencia tiene por base la procedencia de los bienes y valores de su dotación, que, á su vez, son también públicos o particulares; y como los bienes y valores públicos pueden pertenecer al Estado, á la provincia ó al municipio, la beneficencia pública se subdivide en general, provincial y municipal. (Cfr. HeRÁndez Iglesias, F., La beneficencia en España, T. I, Ed. Establecimientos Tipográficos de Manuel Minuesa, Madrid 1876, pág. 140. Y esto a su vez, está fundamentado en las leyes que sucesivamente se fueron dando. Por ejemplo, la ley de 20 de Junio de 1849, en su art. 2 dice: «Los establecimientos públicos se clasificarán en generales, provinciales y municipales. El gobierno procederá á esta clasificación teniendo presentes la naturaleza de los servicios que presten, y la procedencia de sus fondos, $y$ oyendo previamente a las Juntas que se crean en la presente ley". Asi mismo, se ratifica en el R.D. de 14 de Mayo de 1852 en el Tit. 1, art. 1,: «Los establecimientos de beneficencia son públicos y particulares: pertenecen á la primera clase los generales, provinciales y municipales". Y por último, así lo expresa el R.D de 6 de julio de 1853 en sus art. 1 y $3,:$ «...la clasificación de los establecimientos de sus respectivos distritos, clasificándolos con arreglo á la ley, de públicos y particulares, y los primeros de generales, provinciales y municipales". (Cfr. Martínez Alcubilla, M., Diccionario de Administración Española, Ed.3, T. I, Madrid 1877., págs. 889.893 y 902. 
La tradicional beneficencia eclesiástica, creciente en el siglo XIX, va sufriendo paralelas vicisitudes a los avatares políticos que se suceden en el contexto nacional.

El gobierno liberal va asumiendo papeles de protagonista, en medio de este tránsito del viejo al nuevo régimen. El Estado se vuelve intervencionista, desde el punto de vista social y en particular con respecto a las políticas asistenciales ${ }^{68}$.

La asistencia social se entiende como una actividad de carácter público, y en consecuencia, financiada con cargo a ingresos públicos, en base al principio de solidaridad de todos los que viven en una comunidad organizada.

Recordemos, con las palabras de Carasa Soto "Cuando a la burguesía le interesa ocupar el poder social y económico, aspira también a asegurar el poder político. La asistencia y la pobreza deberán controlarse y centralizarse.... de modo que la beneficencia caiga bajo la órbita general estatal... la influencia provincial...y bajo la esfera de actuación municipal, relegando o sustituyendo así el viejo papel eclesiástico pontificio, diocesano y parroquial que pautaba la antigua organización asistencial»" ${ }^{69}$

Este intervencionismo estatal comienza de una forma tímida en sus orígenes, controvertidas y anuladas por sucesivas acciones conservadoras, que más tarde se van afianzando.

También, hay que tener en cuenta a la hora de ver y juzgar todos estos acontecimientos y haceres socio-políticos respecto a la intervención estatal con respecto al tema benéfico-asistencial, la situación por la que atraviesa España en estos momentos históricos. Entre ellas, destacamos la transición del Antiguo Régimen , que respecto a la asistencia social era un tanto artificiosa y mantenida por la fuerza. Otro hecho a destacar es el agravamiento de la situación que experimenta España, a finales del XVIII y en los tres primeros lustros del siglo XIX.

Nos encontramos, pues, con un empeoramiento de las condiciones de vida de una creciente masa de desposeídos, debido al deterioro económico iniciado en los años finales del siglo XVIII y que continúan en el siglo XIX.

Concluimos este artículo, que es un avance de la investigación que estoy realizando para la suficiencia investigadora., reafirmando, en primer lugar la

\footnotetext{
${ }^{68}$ Queremos matizar un poco a cerca del concepto de asistencia social. Y así, se comienza a hablar de asistencia social, aunque con el nombre de «ayuda pública», en la Declaración de los Derechos del Hombre y del Ciudadano en 1791. La aparición del concepto de asistencia social se logra con el tránsito del Estado Liberal de Derecho al Estado social de Derecho, pues el primero se conforma con la mera formulación de derechos, mientras que el segundo contrae el compromiso serio de montar servicios públicos suficientes para dar efectividad a los derechos que ha proclamado la Constitución.

${ }^{69}$ Cfr. Carasa Soto, P., o.c., pág.16
} 
cruda realidad de la pobreza que persiste como problema en siglo XIX. Los pobres, sujetos de pobreza, que a pesar de los cambios producidos, tanto desde el punto de vista conceptual, respecto a épocas anteriores, como desde el punto de vista práctico, o sea, de las medidas tomadas al respecto para la erradicación de la pobreza, siguen hacinándose grandes masas de desheredados, principalmente en las ciudades.

Asimismo, los pobres, son tratados desde la Iglesia como sujetos de caridad cristiana e imagen de Cristo, no ya siendo el centro y la protagonista como en siglos precedentes.

Nos encontramos en un contexto histórico, diferente y cambiante, se ha pasado de una sociedad sacralizada a una sociedad secularizada que busca dar respuestas al problema de la pobreza viéndolos como un peligro social; hay que controlar, diferenciar y centralizar desde una asistencia social estatal, es ya una "cuestión social». 